\title{
Lapurdum
}

Euskal ikerketen aldizkaria | Revue d'études basques |

Revista de estudios vascos | Basque studies review

$8 \mid 2003$

Numéro VIII

\section{« Father, I Accuse Myself » : Basque Women's Self- Depiction in 17th Century Witchcraft Confessions}

\section{Ana Isabel Morales}

\section{OpenEdition \\ Journals}

Electronic version

URL: http://journals.openedition.org/lapurdum/1158

DOI: 10.4000/lapurdum. 1158

ISSN: 1965-0655

\section{Publisher}

IKER

Printed version

Date of publication: 1 November 2003

Number of pages: $359-373$

ISBN: 9782867813436

ISSN: $1273-3830$

Electronic reference

Ana Isabel Morales, « «Father, I Accuse Myself »: Basque Women's Self-Depiction in 17th Century Witchcraft Confessions », Lapurdum [Online], 8 | 2003, Online since 01 May 2009, connection on 02 May 2019. URL : http://journals.openedition.org/lapurdum/1158; DOI : 10.4000/lapurdum.1158 


\section{Ana Isabel Morales}

University of The Basque Country

\section{“Father, I Accuse Myself': Basque Women's Self- Depiction in 17th Century Witcheraft Confessions a}

In April of 1609, Maria Iriarte made a confession in front of the Spanish inquisitors. "When she was asked how many children she had put to death, she first denied having killed any. But after a while she began to cry and admitted she had killed five. The inquisitors encouraged her to give more details, she began to cry again (...) and she confessed to no less than nine child murders. Later she declared, without having been asked, that her mother and sister had taken no part in these murders. When the inquisitors queried this, she corrected her explanation and said that she could not remember them taking part; but if they themselves had admitted it she was willing to confirm it" 2 .

\section{Introduction}

\section{Purpose}

According to Foucault, the production of "truth" through discourse, far from meaning freedom, is "thoroughly imbued with relations of power" 2 . Confession is an excellent example of this. When the power compels one to say everything about oneself, the confessing person becomes a subject in

\footnotetext{
a In this paper, I am looking at confessions of alleged Basque witches of the $17^{\text {th }}$ century and I am paying special attention to these women's subjectivity as it can be read through their depositions. In other words, I am trying to outline the picture of what the power at that period considered "wicked women" to be, and then to explore the way in which "witches" applied this image to their own experience and translated it into their discourse.

${ }^{1}$ Gustav Henningsen, The Witches'Advocate. Basque Witchcraft and The Spanish Inquisition (1609. 1614) (Reno: University of Nevada Press: 1980), p. 66.
}

2 Michel Foucault, The History of Sexuatity, trans. Random House (New York: Vintage Books 1990), p. 60. 
both senses of the word: s/he is the subject under an authority who will assess that confession, and, at the same time, s/he is the speaking subject that constructs that discourse. Thus, confession will speak to us both about the agency of domination that is eliciting the discourse and about the subject who speaks about her/himself under the pressure of that authority. On the other hand, the confessing subject will have to transform her/his experience into discourse using the language regulated and made available by the power.

\section{The 17th c. witch-hunts in the Basque Country}

I am focusing on texts produced at the witch-hunts that took place in the Basque Country at the beginning of the $17^{\text {th }}$ century. Several hunts had been performed before, especially in the $16^{\text {th }}$ century. The particularity of the $17^{\text {th }}$ century witch-hunts is that they happened almost at the same time on both sides of the Pyrenees, the natural border that divides the Basque territory in two parts, peninsular and continental. On the continental (or French) side, the persons appointed by King Henry IV to persecute the sect were judges Jean D'Espaignet and Pierre de Lancre, and they undertook that mission from July to November of 1609. On the peninsular (or Spanish) side, it was the local tribunal of the Spanish Inquisition at Logroño the instance that performed the task between 1609 and 1612. It must be added that this witch-hunt marked a definite turning point in the history of the Spanish Inquisition, due to the disagreement between the three members of the tribunal about the sentences dictated against the alleged witches. The skeptical inquisitor Alonso Salazar Frias distanced himself from his too-believing colleagues, and wrote a series of reports informing the High Committee of the Inquisition about the irregularities he had perceived in the process. He also proposed a series of reforms to be applied in subsequent processes, aiming at transparency and justice in the trials. The High Committee accepted almost all of them. Inquisitor Salazar Frias has been called "the witches" advocate" 3 .

\section{Otherness and witchcraft}

The favorite "others" for witch-hunters since the $15^{\text {th }}$ century were, of course, women. According to Sigrid Brauner ${ }^{4}$, the Malleus Maleficarum was

\footnotetext{
${ }^{3}$ See Henningsen, op. cit.

${ }^{4}$ Sigrid Brauner, Fearless Wives and Frightened Shrews: The Construction of The Witch in Early Modern Germany (Amherst: University of Massachusetts Press, 1995), p. 31.
} 
the first text to assign this gender-specificity to witchcraft. This book was a manual for witch-hunting published in Cologne in 1487 and widely read and used by educated audiences in Europe. Along with a long list of negative stereotypes applied to women, it stated that females are more carnal than males, and, therefore, they will consort even with devils in order to satisfy their insatiable lust ${ }^{5}$. Pierre de Lancre picked up the same idea in his Tableau de l'Inconstance des mauvais Anges et Démons [Description of the Inconstancy of Evil Angels and Demons], the book he wrote as a chronicle of his witch-hunt in Lapurdi ${ }^{6}$. In this work, De Lancre added a tint of local color to the general statements made about women in the Malleus. Since the men of Lapurdi spent half of the year fishing and trading in Newfoundland (Labrador), they never got to really know and love their wives, and these women became only more eager to give their bodies to the Devil 7 . Moreover, their manners, clothes and hairdressing looked so indecent to the judge that he concluded that "c'est un pays de pommes". 8

On the other hand, De Lancre also argued heartily against any active participation of women at church, deploring the existence of the "Benedicts" or female church-assistants in Lapurdi. ${ }^{9}$

A demonization of ethnicity too seems to have played a significant role in the persecution, at least on the continental side of the Basque Country. In his Tableau, De Lancre naturalizes the evil activity he claims to have fought in Lapurdi, by attributing it to the geographic, cultural and economic featu-

5 Heinrich Kramer and Jakob Sprenger [Henricus Institoris and Jacobus Sprenger], Malleus Maleficarum, trans. Montague Summers (New York: Benjamin Bloom, Inc., 1970), p. 47.

6 I use the original Basque name for this province, which in France is called Pays de Labourd

${ }^{7}$ Pierre de Lancre, Tableau d l'Inconstance des mauvais Anges et Démons. Où il est amplement traité des sorciers et de la sorcellerie (Paris: Aubier, 1982), p. 79.

8 Ibid., pp. 83-84.

${ }^{9}$ Ibid, pp.85, 89-93. Speaking about the case of Germany, Sigrid Brauner suggests that the genderbiased construction of witcheraft that takes place in early modernity is due to a shift from a subsidiary role of women to a complementary one. Women within the medieval household were subordinated to men, but they played roles that were interdependent with those of men. In some circumstances, that gave women the opportunity to assume roles of certain authority normally reserved for males (for example, when the man was absent or he died without a male heir). The new idea of gender "complementarity", however, precluded that possibility, because it assigned mutually exclusive spheres of activity to men and women: the public sphere was for men, while women were enclosed within the household. Marriage became mandatory, and women were strictly relegated to housework and child rearing. See Brauner, op. cit., pp. 3-27. I think that Pierre de Lancre's hate for the Benedicts can be read in this context, as well as the presence of women of this profession and an important number of widows and unmarried women among those accused in the Basque witchhunts. 
res of the area. After stating that it is a country located at the crossroads of three kingdoms - France, Navarre and Spain - and a meeting point of three languages - French, Basque (which he calls a "tough" language) and Spanish-De Lancre concludes that all these diversities make Lapurdi a perfect area for the Devil to act. On the other hand, the country's long coast and steep mountains cause the Basques to despise the noble activity of peasantry and to dedicate themselves mainly to sea activities. The continuous contact with such a changeable and unstable element renders these people as inconstant and shifty as the sea itself and, therefore, an easy and ready pray for the Devil 10 .

In short, in Lancre's picture multilingualism is read as a Babelian evil, the element water is synonymous with unstability, an economy based on fishing and trading (especially abroad) is equaled to detachment, and women's gender is translated as lustful and satanic ${ }^{11}$.

\section{The confessions}

\section{Main features}

The texts I am studying correspond to the declarations of women accused of witchcraft in the peninsular (or Spanish) part of the Basque Country. Most of them belong to the Inquisition's records, but there are also texts belonging to the secular Court of Navarre. The main body of the texts is dated in the $17^{\text {th }} \mathrm{c}$., but I will make use of some material of the $16^{\text {th }} \mathrm{c}$. as well 12 .

Leading questions were used to elicit a confession, but they were seldom reproduced in the text. Different means were utilized to compel the accused to speak: from the steady psychological pressure of preachers, priests, family, neighbors and authorities, to different degrees of physical violence (jail, isolation, torture). All the alleged witches in this study decla-

\footnotetext{
${ }^{10}$ See De Lancre, op. cit. pp. 69-81.

II Unfortunately, we do not have a similar treatise or chronicle written by the authorities directly involved in the witch-hunt of the peninsular Basque Country. We can only hint at the important role played by the Spanish Inquisition in the grounding of the national unity of Spain since the accession of Ferdinand and Isabella in 1480. See A. L. Maycock, The Inquisition from Its Establishment to The Great Schism (New York: J \& J Harper Editions, 1969), p. 226.

12 These are the primary sources I have used: Florencio Idoate, La brujeria en Navarra y sus documentos (Pamplona: Aranzadi, 1978), Florencio Idoate, Un documento de la Inquisición sobre brujería en Navarra (Pamplona, Aranzadi: 1972) and Juan de Mongastón (printer), "Auto de fe celebrado en la ciudad de Logroño en los días 6 y 7 de noviembre de 1610", Alfredo Gil del Río, La brujería en el banquillo (Madrid: Editorial el Burgo, 1986).
} 
red in Basque. An interpreter, who was always male, and very often a priest, translated their words orally into either Castilian Spanish or French. A clerk then wrote the deposition as a coherent narrative told in the $3^{\text {rd }}$ person. This clerk was usually strange to the Basque community, and he would often distance himself from the narrative by inserting observations such as "as is the use and custom in this country" etc.

Some of the personnel acted on both sides of the border. For instance, the priest Lorenzo Hualde accompanied Pierre de Lancre as an adviser, assistant and translator during his interrogations in the Pays of Labourd, and later he also worked for the Spanish Inquisition from his recently earned living at Bera, Navarre. He applied the expertise he had acquired with De Lancre in the preaching campaign he led from the pulpits exhorting people to confess, and he acted again as a translator in the interrogations ${ }^{13}$.

The injunctions to speak made both in and outside the church were essential for the elicitation of confessions on both sides of the Basque Country. As Gustav Henningsen argues, "people (...) had to be instructed through preachers or secular agitators before a new mass persecution could be initiated" (p. 391). An indication of this is the statement of Salazar Frias, the skeptical inquisitor at Logroño, at the end of one of his reports to the High Committee of the Inquisition: "There were neither witches nor bewitched until they were talked and written about" ${ }^{14}$. The bishop of Baiona, the learned patron of the Basque letters Bertrand Etxaus, showed a similar skeptical spirit in the continental Basque Country. Apart from releasing some alleged priest witches from jail against Pierre de Lancre's will, he tried to stop the witch-craze by prohibiting further reference to them either in speech or writing ${ }^{15}$.

On the other hand, one of the most important pieces of information to be extracted from an alleged witch was a list of her supposed accomplices. If a person was denounced or mentioned in somebody's confession, this person was in turn accused of witchcraft and arrested for interrogation. The witness' declaration was usually enough evidence to make that person guilty. If the new accused refused to confess, she would be declared a "negative", i.e. one who denied her guilt and refused to cooperate. That would probably mean to be sentenced to be burned alive without being granted the sacrament of

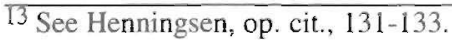

${ }^{14}$ Cited in Henningsen, op. cit., p. ix.

15 Ibid., p. 317.
} 
confession, losing that way both body and soul. Therefore, the most convenient thing was usually to confess to something, and hope for a chance to be "reconciled" with the church and save the soul at least.

\section{Wicked women}

By the time they confessed, these women had quite a clear picture of the identity they were expected to assume, and it was only a matter of time to produce a confession that adjusted to the stereotypical description of the witch made available by the different instances of the power. It is enough to read a few of these depositions to outline the main features of the witch, the wicked woman par excellence:

-She refuses to obey the holy authority of God, embracing instead an evil, alternative one (she renounces her Christian faith and makes a pact with the Devii).

-She shows a deviant sexuality, having unnatural intercourse with the Devil and with her fellow witches, regardless of age, sex or kinship relations.

-She possesses knowledge about birth control (she knows how to prevent conception, provoke impotence, practice abortions etc).

-She is a disturbing element for the stability of the population and the economy by means of her tremendous destructiveness (she kills children and adults, using vampirism or poison; she destroys the harvests and makes fields unproductive).

-She participates in secret meetings with the Devil and her fellow witches, at the akelarres (Basque Aker+Larre $=$ "the field of the male goat") or Sabbaths. There, they confirm their alliance and project their wicked deeds.

-She is always trying to recruit new members for the sect (particularly children) in the hope of weakening God's party and enlarging the Devil's.

As we can see, part of the witch's subversive power lies in her betrayal of women's expected roles of reproduction and nurturing. Paradoxically, she gains nothing from her wicked alliance. The Devil seldom fulfills the promises he makes her, and she is usually one of the victims of the destructive actions she commits (for instance, when she destroys a harvest). As a result, she remains as poor and miserable as she was before becoming a witch. Her deviant practices do not grant her much pleasure: the consumption of corpses 
makes her vomit, and sex with the Devil is usually tremendously painful 16 However, she can not freely abandon the sect, since the Devil and the rest of the witches chases and tortures her if she shows any disloyalty towards the group. In short, she embodies the theological concept of sin, understood as a fall into temptation that grants no reward and makes the sinner lose her soul forever.

\section{Between the lines}

Sigrid Brauner suggests that most suspected witches underwent a psychological transformation as the trial wore on. They would desperately search their minds and pasts for incriminating thoughts or behaviors that would justify the brutal treatment they were suffering ${ }^{17}$, and, I would add, thoughts and behaviors that would make them fit into the picture of the witch already outlined for them. I think that this process can be read between the lines of the confessions I have studied. I will now give some examples of how these women read their lives through the lenses of witchcraft, and translated their "bad behaviors" and there needs, concerns and desires into devilish acts 18 .

\section{a)"Bad behaviors"}

Secret encounters, private female spaces. In the power's picture of them, the witches were not born with their evil knowledge; they had to be instructed by somebody else. This instructor was usually an older woman, in many cases the pupil's mother, a friend or a neighbor. When asked when they were first converted to the sect, many women placed this supposed secret encounter with their instructors in a context of intimacy and solidarity between women. Maria Perez Barrenetxea declared that when she gave birth, a friend came to help her in the delivery, and persuaded her to become a witch by promising that she would have money, pleasure, music, dance and happiness ${ }^{19}$. Maria Periz said that after she gave birth, a neighbor came to see her and promised that she would relieve her from that suffering if she consented to go with her to the akelarre ${ }^{20}$. Maria Etxegi declared that when she gave

16 See Idoate (1972), pp. 134-135 and pp. 140-142.

17 Brauner, op. cit., p. 10.

18 The study attempted here is highly indebted to Louis Jackson's following article: "Witches, Wives and Mothers: Witchcraft Persecution and Women's Confessions in Seventeenth-Century England," Women's History Review 4, no 1 (1995): pp. 63-83.

${ }^{19}$ Idoate (1972), p. 47 
birth she felt miserable and poor, adding that her visitor promised her not only relief from her suffering, but also money to meet her many needs ${ }^{21}$.

This picture of the friend who comes to help or visit a woman around the time of delivery may be related to the figure of the midwife, depicted in the Malleus as an ideal candidate for a witch, due to her knowledge regarding conception and birth control 22 . However, I think that this meeting may very well be seen as a negative reading of a female private space in which women communicate their misery, loneliness and needs.

Another all-female environment often mentioned as a context for secret plotting is that of spinning. In the Basque Country this task was performed exclusively by women. It was very usual that a group of women neighbors should gather at one's house to spend all the night spinning together ${ }^{23}$. Estebania Narbarkorena confessed that the nights the witches had to attend the akelarre, they would often meet at one's home under the pretext of spinning, in order to deceive their husbands and go to the Sabbath after the men were asleep ${ }^{24}$. Mari Joan, her sister and their mother also stayed up late spinning until the time came for them to fly to the witches' assembly 25 .

The distaff would be used as a deceiving tool for daytime illicit wanderings too. For example, Tomasa of Ituren declared that when she went to the mountains in daylight in the company of other witches, looking for lizards and toads to make her poisons, they would bring their distaffs with them to avoid suspicions ${ }^{26}$. Estebania Nabarkorena and Maria Zozaia confessed to having used the same trick when they left the village on foot to go to the akelarres that were celebrated in daylight ${ }^{27}$.

Bad mothers. Oftentimes these women narrated their supposed witchcraft experiences in relation with what they may have perceived as failu-

20 bid., p. 51 .

21 Ibid. p. 51.

22 Heitrich Kramer and Jakob Sprenger, op. cit., pp. 66 and 140-144.

23 There is a Basque traditional song called "Oh, Pello, Pello" that relates the tremendously hard work involved in spinning all night long. It is a highly gendered song too, in which a tired woman asks a man for permission to go to bed, and the man promises her to let her go and hiav her rest as soon as the woman completes certain part of the work. The request for permission is repeated once and again in the song, and the man's answers serve to present the different stages of the task. In the end, the man says simply yes, but by that time it is already daylight, so the woman will not be able to go to sleep.

${ }^{24}$ Idoate (1972), pp. 53-54.

25 Ibid., pp. 54-55

${ }^{26}$ Ibid., pp. 116.

${ }^{27}$ Ibid., p. 148. 
res in their role as mothers. Maria Gonzalez Corres declared that one day she went to the blacksmith's to have a piece of rail fixed. The man was not at home, and Maria decided to wait until night came. However, she was very nervous, because she had left her baby alone. Finally, she started back home in the middle of the night, although she was really scared. It was then when she ran across the witches" Sabbath, and was recruited by them ${ }^{28}$. It is significant that the "birth" of the witch is linked here to the "failing" to fulfill a motherly duty.

Sometimes, these accounts are still more dramatic, when the women accuse themselves of the deaths of their own children. Estebania Nabarkorena declared that when her daughter gave birth to a baby girl, she dressed herself in beautiful clothes. She took the baby in her arms, and the little girl soiled her new apron. Enraged, she consulted the Devil about it, and he gave her some powders to kill the baby. Estebania told her daughter, the baby's mother, that the child had worms, and that those powders would cure her. A few days after eating them, the baby was dead ${ }^{29}$. Of course, we could do a different reading of this account, and interpret, for instance, that Estebania might have noticed in her granddaughter's feces that the child was ill with worms, and she might (or might not) have given her something to cure that disease.

Similarly, Beltrana Farga's deposition may be understood as a perversion of the nurturing mother's role. She said that after giving birth to her baby, she used twice her milk to breast-feed the toad the Devil had given her as a familiar ${ }^{30}$.

Scolding women and sharp tongues. Sometimes these women depict their supposedly evil arts in the frame of their everyday problems with their neighbors. Thus, we find the image of the resentful, scolding woman who quarrels with everybody and is always looking for revenge. For instance, Estebania Nabarkorena confessed to having poisoned a 13-year-old boy because he was always insulting her (surprisingly, the kid died 2 years after being poisoned!). She also said that she tried to kill Katalina Joan Sorarena while she was cutting this woman's hair, because Katalina was contradicting her all the time ${ }^{31}$. Maria Zozaia's confession goes in a similar way. She

\footnotetext{
28 Ibid., p. 51 .

29 Ibid., p. 128

30 Ibid. p. 108.
} 
argued with a woman about a hen, and she got so angry that she killed her with a poisoned apple. Another time, she ordered a dress from a neighbor. She had ordered it full, but the dressmaker made it tight fitting. Maria Zozaia was in a rage. She gave the woman a poisoned pear, and the dressmaker died... six months later 32 . This portrait obviously corresponds with the stereotype of the scolding woman, even including the folklore detail of the poisoned fruits. However, I do not consider it unthinkable that these women might have fulfilled this role in their villages, and internalized their own negative images. Maria Zozaia was certainly a good candidate for that: she was 80 years old, unmarried, and she lived alone in her own house. She also declared that when the young priest at her town passed by her house on his way out hunting, she used to say: "See that you catch many hares, Father, so all the neighbors may have jugged hare". After the man had passed by, she would transform herself into a hare, and run ahead of him and his hounds all day long. The priest would return home exhausted and without having caught a single hare. It must be noted that this story bears a resemblance with a Basque folk tale ${ }^{33}$.

Guilty illnesses. In some instances, these women were compelled to read their health problems in terms of the evilness attributed to them. An extreme case of this is that of Johan of Anozibar. In 1575, this woman declared that she had been arrested because of her bad reputation. Asked what reputation was that, she answered that she was a witch and had done many wicked things. However, when asked about her witchcraft and evil deeds, she only spoke about an apparition that had been torturing her since she was 10 years old (she was 60 now). It was a fearful man, who from time to time came to her saying "you are mine". Whenever she saw this ghost, Johan would faint foaming at her mouth ${ }^{34}$. From a modern perspective, this could perhaps be explained through psychological or physical reasons. We will never know. What we do know is that she never confessed to having renounced her faith

\footnotetext{
31 Ibid., pp. 127-128.

${ }^{32}$ Ibid., pp. 130-131.

33 Mongaston, op. cit. pp. 249-250. The English translation of the mocking greeting of Maria Zozaia to the priest has been taken from Henningsen, op. cit. p. 159. Henningsen also suggests that Maria Zozaia may have been a "scapegoat for the entire neighborhood" (p. 159). The folk tale I think may be related to this passage is called "Martin Abade" or "Mateo Txistu". It tells the story of a priest who, due to his uncontrollable fondness of hunting, one day interrupted the service he was celebrating at church to run with his hounds after a hare. As a punishment for that, he was condemned to wander eternally throughout the world, without ever being able to catch the hare, nor to stop to take a moment's rest.
}

${ }^{34}$ Idoate (1978), pp. 313-316 and 319-321. 
or having committed any crimes, not even when she was subjected to torture. Nevertheless, she was burned alive ${ }^{35}$.

Another, less tremendous, example of this type of formulation is found in Juana Telletxea's confession. She had been chosen to act as the Moor queen in a festival to be celebrated at her village on Saint John's Night. Juana participated in the festival, but on the following day she felt terribly ill and she had to stay at home. In her deposition she explained this by saying that there had been a Sabbath scheduled for that same night, and that when she was in bed after the festival, the witches had come to her and beaten her up for failing to attend their meeting ${ }^{36}$.

Bad wives. As we have seen in other examples, the alleged witches usually declared that they deceived their husbands in order to go to the Sabbaths. Sometimes they would stay up together spinning until everybody was asleep. On other occasions, they would lie down with their husbands and get out of bed when there was no risk to be discovered, as Maria Perez declared ${ }^{37}$. Maria Endara confessed that she had lied to her husband, asking him for permission to go to a night service at the small church near their house, and going to the Sabbath instead 38 . However, this was not the only way a witch could deceive her husband. When they left their homes for the witches' assembly, the Devil would sometimes put a counterfeit body in their place, so no one could notice their absence. Thus, Maria Egilaz confessed that sometimes her husband had had sex with her counterfeit body while she was absent, and that he never suspected the truth ${ }^{39}$.

Apart from making their husbands sin unknowingly with a succubus, the witches would also be unfaithful to them by having extra-marital intercourse in the Sabbaths. Graziana Azpilkueta confessed that the Devil deflowered her at the Sabbath. When she got married her husband noticed that she was not a virgin, and he had ever since reproached her with that 40 .

Bad neighbors and housekeepers. An accused woman was likely to

\footnotetext{
35 Ibid. pp. 324.

36 Mongaston, op. cit., p. 240-241.

37 Idoate (1972), p. 53.

${ }^{38}$ Ibid., p. 189.

39 Ibid., p. 158.

40 Ibid p. 141.
} 
rephrase what could be considered an uncivil behavior within the demonological frame. For example, Maria Zozaia declared that one day a neighbor came to her house to borrow some eggs. The neighbor had to leave emptyhanded, because the Maria Zozaia who opened the door said she had not any. However, this was not the real Maria Zozaia, but the demon that was replacing her while she was at the Sabbath. The demon explained later to Maria Zozaia that he had not known were the eggs were, and that was why he had sent the neighbor empty-handed. Maria Zozaia reprimanded him, saying that "If I had been here, I would have given her some, because I have them over there" (my translation) ${ }^{41}$. I think that this is not a triviality: Maria Zozaia might have felt the need to justify herself in a situation in which she could be suspected of being a bad neighbor, unwilling to help another woman, or a bad housekeeper, who did not have eggs at home when needed.

\section{b) Desires, concerns, needs}

As we have seen in several examples, when compelled to speak about the first time they "agreed" to become witches, many of these women mentioned the promises their instructors had supposedly made them. These promises spoke about relieving them from poverty, physical pain, tiredness, and misery. This gives us an idea of the situation of these persons, who for the most part were poor peasants of the mountains.

Sometimes we can also have a brief glimpse into more intimate details of their lives. For instance, Maria Endara was a young, rich, aristocrat widow who apparently led an easy life in comparison to that of the other accused. What could she wish for? In her confession, Maria Endara placed the time of her alleged conversion to the sect at the time when her husband was still alive. Among the promises she was made, money and amusement were mentioned, but there is still another promise that is insistently repeated in her confession: that she would be relieved from the unhappiness of her marriage. On the other hand, when she spoke about her nights at the Sabbath, she depicted herself gracefully dancing in a ring and holding the hand of Martin, "a quite attractive man" 42.

Incidentally, I would like to underline the important role of class in this woman's deposition. She was a 25 year-old-widow, and a very rich aristocrat. Her difference with respect to the other accused was as obvious to herself as to her interrogators. In her confession, she declared that when first introduced to the sect, the Devil, "a fair and graceful man" (very different from the ugly, dark man described by most of the accused) came personally to greet her with a deep bow. He thanked Maria's instructor (a "serora" or 
female church-assistant) for having taken her, because he had never had the opportunity to welcome such a noble lady into his sect. He ordered his servants to bring a tray full of gold coins, and when Maria tried to take same, he playfully made a sign to the servants to take it away, adding that she would have to renounce her faith before. Maria's instructor then told the Devil that he should not play those jokes to such a high and respectful lady. After that, Maria was invited to join the dance. According to her confession, people were dancing in two different rings: one was the ring of the poor, and the other that of the rich. Needless to say, Maria joined the rich people's ring. After two more visits to the Sabbath — where the Devil renewed his gallantries, always offering her a special seat - she finally agreed to renounce her faith. After completing the ceremony, the Devil offered her a toad, but she turned her face away with a grimace, and it was her instructor who took the toad for her ${ }^{43}$.

There is a still more fascinating element that can be interpreted in relation to the intimate wishes of these women, that is, the sex scenes with the Devil. When interrogated about their sexual encounters with Satan at the Sabbath, the alleged witches met the authorities' expectations by describing something like a ritual rape. There were lots of blood and pain and the Devil's penis felt "hard as a bone" and "cold as ice", just as it is described in the Malleus Maleficarum. Nevertheless, when asked about their encounters with the Devil at their homes, some of the women gave a completely different account, presenting Satan as a sweet lover, who spent much time with them in bed and attended to their pleasure and desires. Graziana Barrenetxea said

4 Ibid., p. 159-160.

42 Ibid, pp. 188-193.

${ }^{43}$ Ibid, pp. 188-193. It is amazing to see how Maria Endara's youthfulness, fortune and class-consciousness influenced also the inquisitors and their assistants, even in the way in which they recorded her confession. A copy of the text was placed separately from the other depositions and signaled with a special heading. Somewhere in the document that contained it, inquisitors Valle Alvarado and Becerra stated that "she was a rich, principal woman of good understanding" (my translation. See Idoate, 1972, p. 52). Looking at her confession, it does not look like the inquisitors importuned her with the usual questions about sexual encounters with the Dark Lord. When she related the scene of her renunciation to the Christian faith, explaining that she had kissed the Devil's left hand, the inquisitors asked her explicitly where else she had kissed him. The person writing the confession recorded how Maria Endara flushed at that çuestion, and answered that she had kissed him nowhere else. The fact of recording such a thing is atypical, and, I think, symptomatic. On the other hand, Maria Endara's charms seem to have made an impression even on nowadays scholars: Henningsen says that she was "beautiful" (op. cit., p. 133), a detail that I have not found in any primary source. Maria Endara was finally released without her fortune being touched, which also seems to have been a special treatment (see Henningsen, op. cit. p. 133). However, she had been imprisoned at Logroño between March and July of 1610, and that terrible stay in the Inquisition's secret cells cost her her life a few months later (see Henningsen, op. cit., p. 482, n. 72 and p. 517 , ก. 17). 
that the Devil hugged and kissed her, and that they conversed in bed ${ }^{44}$. Maria Zozaia confessed that he visited her very often at home, because she lived alone. They had sex and he stayed in bed with her till dawn, and they hugged, kissed and talked to each other ${ }^{45}$. Katalina Porto declared that sometimes they went to bed and spent 3 or 4 hours together, hugging and kissing as man and wife. They talked about love and the Devil told her to amuse herself and have pleasure ${ }^{46}$. Tomasa of Ituren also described leisurely encounters of 3 or 4 hours, in which the Devil treated her as if he was her husband, and they conversed peacefully in bed. Sometimes, before having sex they would also have a snack together! 47

It is hard for me to give an interpretation to the part these sexual and affective fantasies play in the confessions. However, if we keep in mind that these women were trying to fabricate sins and crimes out of their real or imagined experiences, I think it can be argued that a guilty feeling may have accompanied these desires for leisurely sex, tenderness, and partnership. In other words, I would venture to suggest that the women who confessed to these intimate encounters thought that this was something a woman could sell her soul for. It should also be considered that, as Sigrid Brauen explains, "In the late Middle Ages, the Dominican adherents of monastic asceticism insisted on the dangers of profligate sex, even within marriage. For example, Johannes Nider suggests that complete abstinence from sex is the best way to ensure salvation for a married couple. Kramer and Sprenger [the authors of the Malleus] apply such views to their witchcraft theory, arguing that sharing sexual pleasure places a husband and wife in as much danger as an adulterous couple" 48 (emphasis mine). This incrimination of sex, even in its most "domesticated" forms, may have been present in the sermons preached from the pulpits, at least at the time of the witch-hunts. This would have contributed to the inclusion of these kind of romantic scenes (in which sex and company are enjoyed just for their sake) among the possible temptations or guilty fantasies of the Christian woman.

\footnotetext{
Idoate (1972), p. 142.

45 Ibid. p. 143.

46 Ibid., p. 143.

47 lbid., p. 143.

${ }^{48}$ Brauner, op. cit., p. 40.
} 


\section{Conclusions}

In this paper, I have tried to go beyond the stereotype of the witch designed by the power and look for the subjectivity of the women making witchcraft confessions. This is certainly a risky and difficult task, since many layers suffocate the voices of these women. Nonetheless, I think it can be said that, when forced to narrate their "crimes" using the tools of the power, these women judged - and blamed - themselves by superimposing the stereotypical figure of the witch on their experiences in the roles of mothers, wives and neighbors. Their depositions also reveal a negative representation of the private spaces of intimacy and solidarity among women, and give us a blurred but striking picture of their needs, concerns and desires.

I also want to highlight the double mechanism by which these women used the label of witchcraft not only to blame themselves for crimes they had not committed (killing people, spoiling harvests etc.), but also to explain what they probably considered failures in their duties, as in the hope to acquit the real woman by blaming the witch. I consider this to be one of the perverse outcomes of confession, by which the subject ends up fabricating a scapegoat "Other", in order both to meet the expectations of those who will asses her declaration, and to save her dignity before her own eyes.

${ }^{1}$ An oral version of this paper was delivered in a lecture at the Comparative Literature Department of the University of Maryland at College Park in December 1999. 